\title{
FORUM
}

Submitted 04.11.2019. Approved 12.09.2019

Evaluated through a double-blind review process. Guest Scientific Editors: Diego Szlechter, Leonardo Solarte Pazos, Juliana Cristina Teixeira, Jorge Feregrino, Pablo Isla Madariaga and Rafael Alcadipani

Original version

DOI: http://dx.doi.org/10.1590/So034-759020200206

\section{NO POLITICS, NO SOCIETY: QUESTIONING THE JUSTIFICATION OF ENTREPRENEURSHIP IN CHILEAN PUBLIC POLICIES}

\author{
Nem política, nem sociedade: Questionando a justificativa de políticas \\ públicas pró-empreendedorismo no Chile
}

\author{
Ni Política ni sociedade: Interrogando las justificaciones de la política pública \\ pro emprendimiento en Chile
}

\begin{abstract}
Studies show that the state plays a positive role in shaping conditions for entrepreneurship and promoting economic growth through entrepreneurial activity. However, the question of how state intervention in entrepreneurship is justified in neoliberal regimes has received scant attention, although it can legitimize public policies. We examine the entrepreneurial slant of the Production and Commerce Development Corporation of Chile (CORFO), which implements regulations and grants financial support to startups. Analyzing interviews with CORFO's state officials, public statements, and official documentation, we review the advent of state-led entrepreneurial policy and explore the post-dictatorial government's principles justifying current state policy. This policy relies on double de-politicization: i) divesting entrepreneurship from political affiliation and ii) propagating a meritocratic rhetoric of social and individual development, oblivious of structural inequalities. We argue that this is functional for this regime as long as it guarantees state intervention in entrepreneurship as a policy of common good.
\end{abstract}

KEYWORDS | Entrepreneurship, state-led Entrepreneurial public policy, State intervention, Chilean neoliberalism, discourse analysis.

\section{RESUMO}

A literatura sobre a relação entre estado e empreendedorismo mostra que o estado joga un papel positivo na configuração das condições para empreendedorismo e promoção do crescimento econômico através da atividade empresarial. No entanto, a questão de como a intervenção estatal é justificada no empreendedorismo em regimes neoliberais tem recebido pouca atenção, apesar de legitimar políticas públicas. No presente estudo, analisando entrevistas com autoridades estatais da Corporação de Desenvolvimento de Comércio e Produção Chilena (CORFO), declarações públicas e documentação oficial, examinamos o advento das políticas pró-em preendedorismo no neoliberal Chile e exploramos o princípios que justificam a política do estado nos governos pós-ditatoriais. Essa política estabelece uma dupla despolitização: i) despojar o empreendimento de filiação política e ii) difundir uma retórica meritocrática imbuída de desenvolvimento social e auto-realização e cega às desigualdades estruturais. Argumentamos que a intervenção no empreendedorismo se justifica como uma política para o bem comum.

PALAVRAS-CHAVE I Empreendedorismo, política pública empresarial liderada pelo Estado, intervenção do Estado, neoliberalismo chileno, análise do discurso

bernasconir@gmail.com

ORCID: 0000-0002-0685-124X

JUAN FELIPE ESPINOSA-CRISTIA2 juan.felipe.espinosa@gmail.com ORCID: 0000-0002-5629-6328

1 Universidad Alberto Hurtado, Facultad de Ciencias Sociales, Santiago de Chile, Chile

2Universidad Andrés Bello, Facultad de Economía y Negocios, Viña del Mar, Chile

\section{RESUMEN}

La literatura indica que el estado desempeña un papel positivo en la configuración de las condiciones para el emprendimiento y la promoción del crecimiento económico a través de la actividad empresarial. Sin embargo, la cuestión de cómo es justificada la intervención estatal en el emprendimiento en los regímenes neoliberales ha recibido poca atención, a pesar de que legitima las políticas públicas. En el presente estudio, analizando entrevistas con funcionarios estatales de la Corporación de desarrollo de la producción y el comercio de Chile (CORFO), declaraciones públicas y documentación oficial, examinamos el advenimiento de las políticas pro-emprendimiento en el Chile neoliberal, y exploramos laos principios que justifican la política estatal en los gobiernos post-dictatoriales. Dicha política establece una doble despolitización: i) despojando al emprendimiento de afiliación política y ii) propagando una retórica meritocrática imbuida de desarrollo social y autorrealización y cegada hacia las inequidades estructurales. Argumentamos que así la intervención estatal en el emprendimiento se justifica como una política para el bien común.

PALABRAS CLAVE / Emprendimiento, polítioca pública pro-emprendimiento, intervención estatal, neoliberalismo chileno, analisis del discurso. 


\section{INTRODUCTION}

Entrepreneurship enjoys a large following around the world, with approximately four hundred million people actively participating in the implementation or realization of a new business (GERA, 2018). In Chile, this entrepreneurial frenzy is fed not only by the businesses that participate but also by the State. Entrepreneurship has become a top priority for public policies in various areas, ranging from new economic innovation to education for children and adolescents. In $2013,0.24 \%$ of Chile's annual public investment budget was spent on promoting entrepreneurship (Ministerio de Hacienda, 2012).

In contemporary capitalist societies, the boundary between the private and public sectors is always blurry (Duvall \& Freeman, 1981), as long as the public sector is entangled in any process of consumption and production. In the context of entrepreneurship, Adelman (2000) maintained that the government can act as a first mover when there is no private initiative or at least can support financial and other structural conditions to foster private sector action, particularly entrepreneurship. Indeed, several scholars of entrepreneurship policy have confirmed the benefits of state intervention in entrepreneurial activity (Lundstrom \& Stevenson, 2005) as a means of increasing job growth (Birch, 1979, 1981) and national competitiveness (Amorós, Fernandez, \& Tapia, 2012). In Chile, the Organization for Economic Cooperation and Development has studied the effects of entrepreneurial activities in national productivity and growth, supporting the reduction of regulatory "red tape" and the simplification of bankruptcy procedures (Schwellnus, 2010). Examining the case of the Production and Commerce Development Corporation'sCorporación de Fomento de la Producción y el Comercio (herein CORFO) - Start-Up Chile program, the leading entrepreneurial program in the country, another quantitative study measured changes in the "entrepreneurial ecosystem" as an effect of the policy (Mandakovic, Cohen, \& Amorós, 2015). Here, the authors concluded that, "public policy could play a significant role in terms of the design of appropriate institutional and regulatory conditions to support entrepreneurship, especially in developing countries" (p. 122). In discussing Chile, Kantis (2004) contended that Chilean entrepreneurs exploit market differentiation to a higher degree than other Latin American countries rather than embrace innovation. Thus, dynamism and potential growth based on technology is not well developed in the entrepreneurial activities in Chile and demand further State support (see also Benavente et al., 2003). Additionally, scholars working from the viewpoint of developmental economics, such as Naudé (2011), have stressed that fewer start-up creation barriers and permits is a minimum condition for private sector development.

In this context, Naudé explains that the pro-active stimulation of opportunity entrepreneurship is needed. Opportunity entrepreneurship is measured by the percent of adults in first-phase entrepreneurial activities who are exploiting business opportunities. Opportunity entrepreneurship is a significant determinant of economic growth and constitutes activities that develop into dynamic entrepreneurship, leading to the creation of innovative firms and a developmental state (Lazonick, 2011).

Taking a contrasting view, other scholars argue that such economic development approaches can serve as justification for a policy where the state actively acts to foster entrepreneurship. The point of such critical literature on entrepreneurship is to show how entrepreneurship is embedded in political discourse on market ideologies and how entrepreneurial activities lead the economic machine. Weiskopf and Steyaert (2009), for example, have called attention to concepts being disseminated through entrepreneurial discourse, such as the robust entrepreneur, a neopositivist tradition, and optimistic policymaking, grounded in the discourse of neoliberal economic success. Such concepts seem to represent "the holy trinity of the entrepreneur." In turn, Perren and Jenings (2005) critically assessed the State agenda involved in supporting entrepreneurs in their study of the United Kingdom government's entrepreneurial discourse. Here, diverse actors -agencies, banks, consultants, and entrepreneurs, among othersprovide evidence of the potential for a "colonising discourse of subjugation" (p. 181), where entrepreneurs become a "cog" in a neoliberal capitalist model.

At this point, as Foucault (2008) sustained, it is important to distinguish between the promotion of an enterprising culture within an economic system and the cultural hegemony of entrepreneurship as a societal project. Whereas traditional research on entrepreneurship (Casson, 1990 ; Kirzner, 1973), such as Schumpeter (2014[1942]), Sombart (1913), and Weber (2006) referred to its justification within the economic system of production in terms of fostering "innovations," "creative destruction," and "opening of new markets", Marttila (2018) suggests that the legitimacy of entrepreneurship as a societal project involves the dissolution of the distinction between economic and non-economic rationalities of social action. According to Marttila, the blurring of this distinction relies on two shifts; one of "de-differentiation," where the enterprise culture "is decoupled from its previous economic connotation;" and the other of "universalization," where enterprise culture is "made to apply to a range of unprecedented objects of reference such as 
individual persons, public sector, schools, states, universities, working-life, and the like" (pp.4-5).

This article extends this line of thinking Marttila (2018). We do this by examining the entrepreneurial slant of state policy in neoliberal Chile over the past 25 years. Despite the critical position the State can have in entrepreneurial development that goes beyond the economic system, Chile's historical and discursive justification for its entrepreneurial policy has received scant scholarly attention. We investigate this through a case study of Chile's leading state agency in promoting economic activity, CORFO. In the wake of a state-interventionist model, this state agency was founded in 1939 in the context of the 1930s great depression and the massive earthquake that devastated Chile's southern region that year. By boosting national industrialization and an active state role, CORFO emerged to "promote a society of more and better opportunities for all and contributing to the economic development of the country" (CORFO, 2014b, p.1). However, in post-dictatorial Chile (1990-2010), and following the neoliberal reforms implemented in the 1970 s and $1980 \mathrm{~s}$ by the military dictatorship, CORFO shifted into an agency for the promotion of opportunity and dynamic entrepreneurship (Audretsch, Kuratko, \& Link, 2016; Sengupta, 2014); those initiatives that exploit business opportunities - in contrast to necessity and barefoot entrepreneurship (Naudé 2011; Imas, Wilson, \& Weston, 2012). Thus, we understand that in Chile, CORFO represents the main actor triggering what Mazzucatto (2011) calls the "entrepreneurial state."

We approach this case study through an exploration of a repertoire of justifications at the core of the institutionalization of state-led entrepreneurial policies in neoliberal Chile. In the wake of the thoughts of Weber (1975[1905]) and Boltanski and Chiapello (1990), we understand the justification of economic activity as closely associated with the self-perpetuation of capitalism in the current neoliberal era. Further, we suggest that the analysis of the dissemination of ideas around the common good needs to consider the historical processes that support changes in the social realm in a given society; namely, how history affects the way we speak in social interactions and, particularly, the central role state entrepreneurial discourse plays in establishing entrepreneurial culture. Our diachronic analysis of CORFO's repertoire of justifications provides evidence of a double de-politicization of Chilean society at the basis of the process of de-differentiation and universalization of the entrepreneurial culture as a general form of action. We first demonstrate how, at a seminal stage, CORFO developed an explicit ideological label for entrepreneurship as a third-way strategy as a means to advance private initiative. Such a move represented a critical political gesture in a society that, barely out of a 17-year-long military dictatorship, remained deeply divided. We go on to show a second stage when CORFO vested in entrepreneurship the values of individual interests, technocracy, optimism, and others closely related to the neoliberal model implemented during the dictatorship years, justifying entrepreneurship with a plethora of arguments-ranging from job rates to human dignity; from innovation and creativity to the realization and emancipation of the self. This rhetoric maneuver, we argue, helps to conceal capitalist accumulation and exploitation in a highly unequal society while entwining economic and non- economic social action within entrepreneurial rationality. In other words, the institutionalization of state -led entrepreneurial public policy relies on two highly ideological operations of de-differentiation: one by which entrepreneurship is divested from political affiliation; the other, based on ignoring Chilean society's exorbitant social inequalities. These operations open the way for the universalization of the enterprising culture through a meritocratic discourse whereby entrepreneurship is disseminated as a panacea for all. These processes, we argue, enable the State to support entrepreneurial activity as a matter of common good.

The remaining article structure begins with a conceptual framework, which is followed by the description of the case study and data set we examined. Next, we present a brief historical narrative of the neoliberal change in Chile as a prelude to the analytical section on CORFO's growing repertoire of values imbedded in entrepreneurial activity over the years. Then, we discuss these findings to argue that state-led entrepreneurial justification in Chile goes beyond economic goals and relies on a double de-politicization of society, which is useful for the selfperpetuation of the neoliberal regime. Finally, in the conclusion, we show that entrepreneurship justification by the State leads us to a better understanding of its policies not merely as instruments that foster entrepreneurial activities, but as an outlook that shapes the society we inhabit in Chile. This society is one where entrepreneurship is de-politicized from the right- and left-wing historical ideology and is culturally de-differentiated, leading to the subsuming of any value under the entrepreneurship society.

\section{JUSTIFYING ENTREPRENEURSHIP}

Classic (Weber, 1975[1905]) and contemporary social thought (Boltanski \& Chiapello, 1999) conceives of the promotion of economic activity as an endeavor that is not exclusively based on capital accumulation but also on adherence to general values that present capitalism as an acceptable and desirable order. 
Justifying a pro-entrepreneurial policy implies being equipped with a moral repertoire that can be applied to concrete activities (Boltanski \& Thévenot, 2006). Young (2004), Harding (2007), Lamont (1994), Lamont and Small (2008), Colonomos (2005), and Finnemore \& Sikkink (1998), among others, have advanced this vision of morality as a "cultural toolkit" (Swidler, 1986) used, for example, to produce boundaries between social groups; the so-called "moralization of capitalism" (Colonomos, 2005). In this sense, we assume that the State, through its public policies, may pursue cultural intervention, promoting a discourse on the value of entrepreneurship with a pretension of truth. Therefore, the State's arguments not only "must take account of their context," but also "must be specific and relevant" (Keith \& Rehg, 2007, p. 215); that is, be plausible, viable, and acceptable to the situation they are used in.

However, ideas about the common good do not emerge in a vacuum. They arise from historical processes that support change in the social realm where people live and engage in social and economic relations. Working from different latitudes, Foucault (2008), McNay (2009), and Bröckling (2015) have demonstrated that a discursive rhetoric consistent with the morality and politics of neoliberalism permeates the social market economy. Similarly, we need to consider that State discourse is embedded in historical roots. As Goodwin (2018) indicated, the history of any activity is intrinsically related to the form in which communication occurs. Therefore, history is not external to policy enactment; it is alive in the associated interactions and, in our case, in how actors use different devices to deploy entrepreneurship policies.

Moreover, in line with recent studies, we understand that State policies and the surrounding discourses through which they are communicated and disseminated, are not merely instruments that foster entrepreneurial activity. These discourses that justify public entrepreneurship policies are avenues that frame and construct the very phenomena they are addressing, as Örge (2013) has shown through a study of the Turkish government's entrepreneurship policy. Following this line of thinking, we take inspiration from Foucault's treatment of discourse, which focuses on what speech does or what discourse institutes (Holstein \& Gubrium, 2013). We also understand discourse as an active process of composition (Brown 2001, p.180), organization, designation, and acceptance of a given entity.

\section{CASE STUDY}

Our analysis here is based on a research project led by one of the authors. The project's goal was to explore how entrepreneurship was practiced across a socioeconomic spectrum - from microcredit solidarity lenders to high-tech entrepreneurs. Additionally, the project studied the stages of entrepreneurial development; the startup, the rollout, and ongoing management of the business.

The project had two phases. The first involved a general exploration and description of the entrepreneurial system, aimed at identifying the actors, programs, and policies in Chile that promote entrepreneurship. To do this, public entrepreneurial events were observed and interviews were conducted with 24 different actors (some just once, and others in two or three sessions), including professionals at private and public agencies, entrepreneurs, mentors, investors, and coaches. The second stage, based on ethnographic techniques (field observations, interviews, document classification and analysis, review of web pages, etc.), was an in-depth examination of concrete entrepreneurial activities. Ten ventures met or derived by other parties during the research process in Santiago were selected to trace commonalities and differences in the way entrepreneurship was practiced in three main scenarios identified in the previous stage. The scenarios were defined by the public (ministries, public policy, public funds) and private actors (incubators, training programs, intra-organizational initiatives) as: i) self-employment for the inactive poor, ii) small businesses for technical workers usually of the middle class, and iii) high-tech, innovative and scalable projects often led by upper-middle class professionals. The cases were: four startups in different stages of development to cover a venture's full trajectory in less time, four organizations that worked with entrepreneurs daily (an innovation Centre, business incubator, scientific entrepreneurship promotion Centre, and microcredit institution), the creation of the trade association of entrepreneurs in Chile, and the development and transformation of public policy on entrepreneurship since 1990. In total, the project conducted 66 interviews, 85 field observation sessions, and gathered documentation on 25 organizations.

This article draws on data from the research on the development and transformation of entrepreneurship public policy. Specifically, we explore the discourse of the actors who enacted state-led entrepreneurial policies in Chile. To do this, we analyzed interviews and documents related to CORFO. The data set was composed of i) 59 documents pertaining to CORFO's entrepreneurship programs, ii) notes and transcripts from a two-day introduction to CORFO's public programs from one of its officials, and iii) interviews with three former CORFO executive vice presidents (in the period 1997-2012), two CORFO assistant managers, and two CORFO intermediate-level officials. To complement these interviews, we also analyzed speeches delivered by public officials, such as the Minister of Economy, 
at the time. The content analyzed included justifications for entrepreneurship, either spontaneously or in response to our questions. To analyze the discourse, we adhered to the general guidelines developed by the Loughborough School (Antaki et al. 2003; Potter \& Wetherell 1987), which follows, among others, Michel Foucault and poststructuralist thought. Notably, we focused on the rhetorical dimensions of entrepreneurial discourse -that is, the capacity of the text to achieve its purposes (e.g., to persuade and gain legitimacy). Thus, discursive analysis is mainly based on a subtle and context-based understanding of text in that context. In the following, we offer a brief review of Chilean economic history during the 1970 s and the 1980 s as a way of giving depth to the analysis of CORFO's policymakers' justifications.

\section{THE ADVENT OF NEOLIBERALISM AND ENTREPRENEURSHIP}

Imas (2010) convincingly explained that Chile's recent history represents an "ideal" construction of a society under the principles of neoliberalism. This neoliberalism was implemented during the bloody military dictatorship led by General Augusto Pinochet (1973-1990). As Chilean historian Verónica Valdivia (2010) has argued, the political challenge during the dictatorship was not only to annihilate the institutionalized left and demobilize society, but also to dismantle the political culture rooted in the country throughout the 2oth century. This political culture was based on a preponderance of political parties in the State as an entity that expressed citizen demands, and a system of constitutional guarantees based on political and social freedoms. The dictatorship replaced the principles of collectivity and solidarity with that of individual interest; it reduced state powers and introduced technocratic approaches to political decisions (Imas, 2005).

Consequently, the Junta dismantled Chilean political culture and transferred social regulation to people and the market. Indeed, the neoliberal "brainwashing" involved not only the economy but society as a whole (Imas, 2005). Juan Andrés Fontaine (1993), an economist trained at the Chicago School in the free market and monetarism political ideology, explained that a vital piece of Chile's neoliberal project was to radically reverse the interventionist regime; and, to remove almost every single redistributive policy in the Chilean economy. Although the new military junta quickly began to suppress the control of prices and regulations to reform the tax system and return nationalized companies to private hands, the transition to a free market-based economy began when Minister of Finance Jorge Cauas, announced his draconian “Economic Reconstruction Plan” in 1975. This plan involved economic policies and social reforms guaranteed with legal changes approved by ad hoc commissions appointed by the dictatorship. Since the 1990s, state-sponsored entrepreneurship and related policies have renewed the commitment to the neoliberal regime in Chile. However, policies that embrace intervention that fosters entrepreneurial activities have not changed the fundamental type of capitalism implemented during the 1970 s and 1980 s in Chile. This phenomenon, where things change but at the same time remain the same, demands a careful analysis of discourse strategies. In the next section, we disclose this discursive maneuvering based on our diachronic analysis of state-policy documents and interviews with CORFO officials.

\section{Renewing the commitment to capitalist accumulation in neoliberalism}

\section{A sociogenesis of entrepreneurship as state policy}

For an activity to emerge, it must generate interest. Within the so-called Chilean "entrepreneurship system," several milestones have stimulated interest. In the 1990s, CORFO marked the first of these milestones when it shifted its politics toward "the care and promotion of private enterprise" (Former CORFO executive vice president, personal communication, April 28, 2012). The advancement of entrepreneurship and innovation aimed at increasing economic productivity was the means to that end. First through the Ministry of Economy and CORFO and then through the Solidarity and Social Investment Fund (FOSIS), under the Ministry of Social Development.

At the beginning of the 1990s, a democratic government was re-established following 17 years of military dictatorship and the implementation of a profound neoliberal set of reforms. A group of center-left professionals, composed mainly of economists, lawyers, and engineers, entered the political administration. Several had previously lived in exile in Europe and witnessed the renewal of the left's political thinking. They returned to Chile inspired and willing to stop viewing the entrepreneur through the lens of Marxist class conflict and adopt the Schumpeterian vision of the entrepreneur as an innovator (former CORFO vice-president, personal communication, May 7, 2012). The argument put forward by Austrian economist Joseph Schumpeter (1883-1950) was that the dynamics of capitalism depend on the ability to innovate and that such innovations are generated by entrepreneurs, or "wild spirits" who challenge the establishment. One of CORFO's former vice presidents explained this in an interview. 
The modern concept of the entrepreneur is an ideological way to recover the idea of the private business owner as the engine of development minus the burden that the idea of capitalist accumulation had (...). First, we went one way: socialism. Then, we went the other way: neoliberalism. And in the end people say 'hey, let's take care of the private sector, particularly the innovative sector, which is generating new activity, we'll call that entrepreneurship'. (Former CORFO executive vice president, personal communication, April 28, 2012)

This former CORFO executive placed entrepreneurship in the middle of two alternatives considered mutually exclusive societal models-socialism and capitalism. These two models had in the previous three decades not only been tested in Chilean society but had also supplanted one another via the force of a bloody military coup d'état that practiced state terrorism against the previous regime's supporters. At the dawn of Chilean society's political transition, entrepreneurship appeared as a third model. The construction of this alternative is necessary to understand the boldest concept in the quote: divesting entrepreneurship of "the burden of capitalist accumulation" associated with rightwing ideologies that supported the coup. Once distanced from the two main ideologies of Chilean society's contemporary history, the path of entrepreneurship would be free to appeal to all who are or who wish to situate themselves somewhere in between. With this maneuver, CORFO produces fertile ground for the State support of entrepreneurship.

In the extract, the executive also gives voice to those who understand that an innovative private sector generates economic activity. Through this approach, he constructs a reality external to himself (Potter, 1996) and separate from his opinion. The Chilean transition public policy agents agreed to call this private innovative initiative "entrepreneurship." Entrepreneurship, then, can renew a general commitment to capitalist accumulation. This discourse inherits the whole "ideological" gesture of the Chilean neoliberal regime at the dawn of the 1990 s. According to this former vice president, however, initially there was no consensus regarding the "social impact" of entrepreneurship. On the one hand, the nascent state programs and policies that subsidized entrepreneurship generated controversy among the right's elite; especially among "those technocrats who were worried about the return of state intervention mechanisms within the economy" (Former CORFO executive vice president, personal communication, April 28, 2012). This official reminded us of a recent precedent in this respect. In the 1970s, during the popular government of socialist president Salvador Allende, "CORFO had been the big holder of more than 500 nationalized companies" that later, during the military regime, became privatized following an economic plan that advocated a drastic reduction in the State's participation in society. On the other hand, the new policy of incentivizing private initiatives created tensions for the economists of the outmoded left. Those economists considered the allocation of state money to finance the country's entrepreneurs unjustifiable. Against this backdrop, the ideological shift of the 1990 s was bolstered by a global phenomenon that began at the end of the decade: the so-called "Dotcom Bubble." This phenomenon highlighted the lack of support tools from the State for new businesses and startups. Another former CORFO executive vice president stated it this way.

In Silicon Valley...a group of companies begin to appear...Yahoo, Amazon...with a business model that grows very quickly...a new entrepreneur who gets established and grows very fast. But CORFO's framework of instruments and programs...was intended only for existing companies; that is, we had nothing for a person who wanted to start a company. (CORFO Manager, personal communication, February 6, 2012)

This describes an international economic reality that moves faster than any CORFO tool would to develop Chile's domestic economy. Once again, this reality appears as an external construction affected by two actors: innovative entrepreneurs acting quickly and the State (CORFO) moving slowly. A third actor was introduced into this scenario, Silicon Valley, which operates as a common ground for innovative technological entrepreneurship; that is, the "benchmark" to emulate. The message here was that the nation's instruments and programs were not attuned to this inescapable international reality-an economy based on innovative technological entrepreneurship. Additionally, the executive discourse expressed that the alignment of national policy is a matter of keeping pace with global developments, a formula with a long tradition in political economic literature in America's Southern Cone (see Fleming, 1979; Lipset, 1967; Germani, 1970). The point of this discursive maneuver was, we argue, to divest once more a State decision of political elements.

Consequently, CORFO's instruments to foster entrepreneurial activities, frame and construct these themes accepting and aligning the State towards an international global political economy (Örge, 2013).CORFO, thus, assumed the task of designing "a resource-heavy policy towards new 
enterprises with greater potential for growth," (Former CORFO executive vice president, personal communication, April 28, 2012) creating "instruments" for this purpose -that is, programs that “systematically search for business ventures" (Entrepreneurial acceleration agency manager, personal communication, May 14 , 2012). Thus, in 2005, INNOVA-CHILE emerged, a component of CORFO designed to "support the development of new businesses, the creation of new enterprises, as well as to foster entrepreneurial skills in the country" (CORFO, 2014a).

While entrepreneurship as public policy began with the advent of the Concertación Coalition, the center-left coalition of political parties that led the democratic transition after the military regime's 1988 defeat on the polls, this brief sociogenesis of stateled entrepreneurial policy in Chile shows that the entrepreneurial regime emerged from a complex web of State policy justifications that connect the neoliberal Chile of the 1990s with that of the 1970s. Nonetheless, the ideological dissemination of private enterprise, as a politically purified activity, was not triggered by the dictatorial regime's rightwing technocrats, but rather by leftcentered ideologies during the democratic transition. In this context, entrepreneurship emerges as an alternative to the traditional capitalism of large corporations/companies, once divested of the burden entailed by the processes of capitalist accumulation. This entrepreneurship policy discourse de-politicized entrepreneurship from rightwing neoliberalism and from its leftwing inheritance. De-politicization rhetoric is enacted in a new space, where the new concepts relate to entrepreneurship.

\section{Innovation through productivity: entrepreneurship's} moral guarantee

As of 2012, the association between entrepreneurship and innovation was still at the center of the justification rhetoric in Chile. In our interview, CORFO's entrepreneurship program manager at the time discussed it in the following terms.

The initial question is, why do countries decide to support entrepreneurship? That is founded on economic theory; there is evidence that societies that are more entrepreneurial achieve greater productivity levels than those that are less; therefore, countries that are in an economic stage like Chile's, which is a stage of transition...between underdevelopment and development...have to take the issue of innovation as an important element within politics, and unfortunately our soci- ety, because of the characteristics it has had, is a society that has trouble being innovative, because of cultural issues and because of economic issues too (...). So states have to make up for this through policies proactively. (Former CORFO executive vice president, personal communication, April 28, 2012)

Similar diagnosis can be found in the Chilean government's 2006 report from the National Innovation Council for Competitiveness, which served to justify the "Seed Subsidy of Flexible Allocation for Entrepreneurs," one of CORFO's leading entrepreneurial programs; and, in the foundational "background report" of the Chilean National Council for Development and Innovation: "If Chile does not advance, soon and fast, on innovation and technological transfer, the country will start lagging behind, to the point that its current static competitive advantages could be seriously threatened and displaced" (CNID, 2006, p.11). Through this line of argument, entrepreneurship has been placed in the evolutionary trajectory of economic and social progress, and Chile, in an intermediate but promising stage at a global scale.

Concepts of change and innovation are channeled into the construction of the image of Chile as an entrepreneurial society. In this discursive strategy, social change is reduced to development, development to increased productivity, and innovation (specific to various fields such as art, science, technology, culture, and sociality, among others) to the sphere of business. Thus, a society that is innovative and even developed becomes an entrepreneurial society, one that would justify pro-entrepreneurship policies insofar as its ultimate purpose is social development (having already set aside unlimited accumulation as its goal). In sum, if the justification for an entrepreneurial society is based on concentrating the ideas of change and innovation into the field of business, the promise of its effects surpasses this, blessing the goal of "social development." The reference to the role of Chile's culture in this trajectory is another discursive maneuver aimed at de-differentiating the social context where entrepreneurship operates. Instead of calling for the integration of entrepreneurship into national culture and social diversity, State discourse not only points to Chilean culture as an obstacle for an entrepreneurial society, but identifies it as one of the reasons for public intervention in entrepreneurship. The diagnosis is that Chile needs to adapt to an entrepreneurial culture quickly; the world demands it. Our entrepreneurs' must have resources that operate with the same speed as the market and the State must align with this need.

In short, the State policy discourse associates entrepreneurship and innovation so closely it makes them 
indistinguishable. To quote a CORFO manager, "entrepreneurship is the concretization of innovation". According to this reasoning, the "evidence" shows that any country wishing to attain rapid development must increase its productivity. Entrepreneurship is a means to that end. CORFO's slogan, "dream, venture, grow," situates entrepreneurship in a mediating role. It is important to remember that at the moment of its inception in the 1990 s, entrepreneurship also had this intermediate position between two political poles. In this case, entrepreneurship's "moral guarantee” lies in its ability to increase economic productivity by creating innovation. CORFO's discourse shapes entrepreneurship as the possibility for innovation and social development, something that it is always good and acceptable for the country.

\section{Entrepreneurship as a Hyper Good}

In the last years, the entrepreneurial discourse has added new concepts and actors. In fact, according to the current promoters of this, in conjunction with being the "hypergood" of growth (Taylor, 1989), entrepreneurship brings with it several benefits, a common good, and "positive externalities." First, it plays a cohesive and redistributive role. In countries like Chile, where wealth tends to be concentrated in the hands of a few economic actors, developing a tremendous entrepreneurial capacity would redistribute wealth among a more significant number of small business owners. Mainstreaming entrepreneurship would allow "homogenization" to take place and offer "an umbrella that brings together and helps close the inequality gap" (CORFO Manager, personal communication, February 6, 2012).

For those who fail to become integrated as entrepreneurs - that is, the poorest - the success of those who are able can bring benefits to the extent that the expansion of entrepreneurship will make the market more efficient, thereby becoming a tool of inclusion and another means for neoliberal ideological principle support (Harvey, 2005; Fontaine, 1993). In the following excerpt, a CORFO manager alludes to the famous "trickle-down theory" espoused by the promoters of Chilean neoliberalism, and closely linked to the history of neoliberalism (Harvey, 2005).

If one believes in this economic model, all people must be reached, and the trickle-down path takes a long time. We could include these people in the economic model and not segment them, not stigmatize the base of the pyramid, an atrocious term [he clarifies]. According to CASEN [na- tional survey of the population's socioeconomic traits], this is $15 \%$ of the population; it's a lot of people who consume, to begin with. However, they pay more for sugar, oil. There's a hidden economic power there, which you can open and give them dignity as buyers, from a public policy perspective; it's an inclusive tool. (CORFO manager, personal communication, April 24, 2012)

The "base of the pyramid" concept comes from the literature on first world business education. It refers to the four million poor who are neglected throughout the world by the organized private sector (Prahalad, 2006). More broadly and referring to Chile, CORFO (2012, p. 3) understands the base of the pyramid as those Chileans classified in the lowest income quintile. In CORFO's manager rationale, an entrepreneurial society fosters social cohesion because it integrates even the poor into aggregate demand (via consumption). Additionally, the manager concedes that "base of the pyramid" is an "atrocious" concept. Thus, a discourse covering the concepts of dignity, consumption, inclusion, and the terrible/inhuman is used to create an entrepreneurshipinclusion pairing to make entrepreneurship more appealing, even for those who are unable to embrace the entrepreneurial class directly but can benefit from its success (the poor).

At this stage, the policy discourses among the higher authorities put more emphasis on the benefit of job creation resulting from new ventures, and, thus, on the capacity of entrepreneurship to lead societal change. In an excerpt from a speech given at the inauguration of the 2011 Global Week of Entrepreneurship, the Minister of Economy under President Sebastián Piñera's former administration (2010-2014) stated the following.

We want to turn entrepreneurs into people who contribute most toward social change in Chile, each talented entrepreneur who begins a journey is someone who creates jobs, who creates employment and helps improve the dignity of all Chileans, no matter what many say, there is no one more supportive than entrepreneurs, than those who dare, those who embrace the adventure of developing the talents that each one of us possesses. (Longueira, 2012).

In this, the concept of "social change" is incorporated, implying that there is no area in society that entrepreneurship could not contribute to. The theme of the quality of that change 
is not considered, instead following a strategy that transfers the benefits of change to its effect. The speech idealizes entrepreneurship and pairs it with concepts such as dignity, solidarity, and social change, ignoring the equally potential realities of job insecurity and individualism, which not only differ but also conflict with the promoted values. Moreover, the speech excludes central aspects of the economy, such as competition for scarce resources, necessary creative destruction, as analyzed by Schumpeter, and the inevitable mistakes and failures that such entrepreneurship entails. It furthermore raises the entrepreneur to the rank of a hero who suffers the "loneliness" of the "adventurous" act in line with the image of the cowboy, as referenced by Kaulingfreks, Lightfoot, and Letiche (2009).

In short, entrepreneurship is shown as a means for individuals' inclusion in the economic system, either through consumption or work. Whether it is in the offer or the demand, such justifying policy discourse grants human beings a moral sense of dignity. Unlike yesterday, the value of dignity is not anchored in collective projects, solidarity, and finite human needs (Max-Neef, Elizalde, \& Hopenhayn, 1990) but rather in the inclusion of individuals in the market economy.

"At the end of the day, we talk about entrepreneurship because we believe it's a very powerful tool for social mobility, firstly, because it generates income and secondly, because it generates dignity. It makes you part of the system". (CORFO Manager, personal communication, February 6, 2012)

However, the constructed reality excludes from its discourse the unexpected effects of the policy that originates and disseminates the reality. For example, politics is simplified by encouraging a type of entrepreneurship that would increase social cohesion, close the inequality gap, and, even among the poor, operate via a "trickle-down," reducing the phenomenon of exclusion by incorporating this population as aggregate demand. Finally, this discourse recognizes human dignity as an individual ability and resource of self-generation. This concept, as discussed by the CORFO manager, is what is genuinely "atrocious" about the way this regime has developed in the past decades in Chile.

\section{Discussion: the double de-politicization of entrepreneurship}

The Chilean State entrepreneurial slant is a means for the renewal of neoliberal Chile's commitment to capitalist accumulation in the post-dictatorship era. Discursively, entrepreneurship emerges in Chile through its differentiation from the main ideological currents (it belongs neither to the Right nor the Left) and with the promise and urgency of becoming the engine of societal and individual change. This approach represents an epic and luminous story for a transitional society fresh from its worst political and moral catastrophe. Twenty-five years later, entrepreneurship is associated with other values that complement that initial rhetoric, such as job and income creation, inclusion, and human dignity. This gradual and systematic expansion of the justifications in the repertoire of entrepreneurship is indicative of the growth of the neoliberal governmental economic rationality.

Underlying the practical realization of entrepreneurial projects and granting sense to the act of enterprising, the stateled entrepreneurship policy relies on the production of a precise subjectivity (Bröckling, 2015). In the words of one of CORFO's managers,

The good thing of entrepreneurship is that it allows you to discover yourself, to take care of yourself, to own yourself, self-entrepreneurship means that you are who you want to be. You make a living out of that, and you operate as if you were a company, in the sense of planning, strategizing. And on a personal level, I think that's good. There's learning in entrepreneurship that helps people be what they want to be part of the system. (CORFO Manager, personal communication, February 6, 2012)

At this intrapersonal level, entrepreneurship is specified through the very experience of enterprising, regardless of the achievement of any economic goal. Indeed, entrepreneurship becomes a means for individual self-realization. Ultimately, the state-led entrepreneurial discourse addresses a demand for a substantive transformation of the individual into an asset which, in turn, leads to the intensification of the neoliberal entrepreneurial society. Moreover, this strategy promotes entrepreneurship as an individual "skill" or "talent" that anyone can develop regardless of socioeconomic position or competencies. To the extent that entrepreneurship requires "talents" that anyone can develop, the activity disseminates in meritocratic fashion (it depends on myself only), without acknowledging distinctions of class, ethnicity, origin, sex, or capital. This strategy ignores the existing structural arrangements and extensive inequalities in the Chilean population, (where, according to data from 2012, the proportion is 9.5 of the average of OECD [1996] countries) (Retrieved from 
http://www2.compareyourcountry.org/crisis-impact). Therein lies, in part, the discursive fertility of the pro-entrepreneurial lexicon. On the one hand, as Beckert (2013) points out, the characteristic of entrepreneurial meritocracy tries to protect entrepreneurship from the effects of the structural barriers of stratified and unequal societies, like Chile's, that can hamper the upward mobility promised by enterprising activity. On the other hand, the discourse excludes key questions such as whether Chileans possess the same capacity to innovate or networks to create the right teams and secure financing at an early stage, as it is required in most seeds subsidy programs). According to Tirado and Domenèch (2009), the task of meritocratic discourse is precisely to make skills look like resources emerging out of isolated beings who are no longer dependent on a wider network of alliances, positions, and support (p. 252). This discourse is appealing to a general and broad audience.

The second discursive maneuver of state-led entrepreneurship policy is based on the enactment of a homogeneous and smooth social fabric (Deleuze \& Guattari 1980) where entrepreneurship can be de-differentiated (Marttila, 2018), decoupling the concept from previous economic and ideological aspects related to the culture of the enterprise. At the same time, this maneuver separates entrepreneurship from any unequal distribution regarding capabilities, ideologies, and power struggles. Similarly, because all resources required for this activity are conceptualized within the semantics of "individual skills," no notion of sociality seems necessary beyond the network of mutual benefit on which entrepreneurship is sustained. This is a second central concept that supports this discursive framework: to assume that entrepreneurship does not require society, or, more strictly, that it requires no other company than the "entrepreneurial society." In the words of CORFO's manager, a "more entrepreneurial society would be a more self-reliant society, owning more of the things that happen to us, [with] more ownership" (personal communication, February 6, 2012).

Placing these two maneuvers in historical perspective, a third appears. In the review of 25 years, we detected that the proentrepreneurial state discourse in Chile recurred and displayed a double de-politicization of entrepreneurship: 1) at the moment of its emergence, where the political affiliation of entrepreneurship is stripped away (it belongs neither to the Right nor to the Left) and 2) today, where the State's discourse avoids the role of power games and structural inequalities in the shaping of entrepreneurial activity in Chile. In this way, the justification of pro-entrepreneurial public policy in Chile excludes the role of society and that of politics and in this way contributes to the de-differentiation and universalization of the entrepreneurial culture.

\section{CONCLUSION}

In this article, we attempt to contribute to the literature on entrepreneurship policy by filling the gap in the research on Chile's public policy entrepreneurship justification. Our analysis considers public policy official discourses of CORFO, its highest government entrepreneurship agency. Taking this case, we shift the analysis from public policy entrepreneurial evaluation to a study of the State entrepreneurship policy justification. Our diachronic analysis sensitive to the historical trajectory of this society has enabled us to understand better the cultural, political, and economic processes with which entrepreneurship development intertwines.

The Chilean neoliberal system uses entrepreneurship universalization discourse for the sake of its perpetuation. Contradictions arise because, paradoxically, to actively promote entrepreneurship leads to certain principles of neoliberal ideology, like non-intervention in markets and the economy. However, the contradiction is only apparent because state entrepreneurship discourses decoupled from previous economic ideology create a place where entrepreneurship subsumes any cultural message and significance, universalizing entrepreneurship. The investigation of entrepreneurship state justification leads to understanding these policies not merely as instruments that foster entrepreneurial activities, but as a means to shape the society that we inhabit in Chile. CORFO's rhetoric intensifies the values of individualism, technocracy, personal interest, and optimism. In this sense, the justification of state-sponsored entrepreneurship sheds new light on how entrepreneurial subjects can permanently accept the uncertainty that neoliberal society imposes.

Entrepreneurship support becomes merely propaganda to sustain ideas that have a long historical tradition related to dictatorship times. Such propaganda is not harmless and creates double de-politicization where the ideological affiliation of entrepreneurship is stripped away from rightwing historical neoliberal roots. Additionally, entrepreneurship state-led policy avoids acknowledging the role of power games and structural inequalities in the shaping of entrepreneurial activity in Chile, producing a new pervasive bio-psychological entrepreneurial culture. This culture is based on the fall of community values, the rise of personal talent, and the occlusion of any reference to privilege. The "entrepreneurial society" envisioned by the Chilean State's discursive justifying strategy is reminiscent of Margaret Thatcher's belief of society to be a mere illusion, since "there is no such thing as society, there are only families" (Thatcher, 1996).

Further research on public entrepreneurship policies is needed. For example, a detailed examinations of entrepreneurial 
policy justification rhetoric, that may trace links between State discourse on entrepreneurship at the local, national, and regional levels. A more robust analysis of entrepreneurship justification demands the inclusion of historical, political, and cultural factors. Overall, it is now clear that more culturally sensitive research is required to understand entrepreneurial activity and its effects. Researchers need to engage in cultural-comparative studies to fully assess the principles on which the institutionalization of the State becomes a tool for neoliberal justification and therefore, for this regime's self-perpetuation.

\section{ACKNOWLEDGMENTS}

The authors wish to thank the valuable comments of the reviewers, Max Tham and Felipe Mallea for early contributions in the literature review process and the funds that made possible our research: Fondecyt $n \cong 11110459$, "Individuos y regímenes pragmáticos en Chile: hacían una sociología pragmática y moral del individuo" and Anillos SOC180039 "Knowledge production in contemporary Chile" funded by the Chile's Science and Technology National Commission.

\section{ETHICS AND CONSENT}

Authors declare that the research was performed in accordance with the Helsinki declaration.

\section{REFERENCES}

Amorós, J. E., Fernández, C., \& Tapia, J. (2012). Quantifying the relationship between entrepreneurship and competitiveness development stages in Latin America. International Entrepreneurship and Management Journal, 8(3), 249-270. doi: 10.1007/s11365-010-0165-9

Antaki, Ch., M. Billig, M. Wetherell, D. Edwards, \& J. Potter. (2003). Discourse analysis means doing analysis: A critique of six analytic shortcomings. Discourse Analysis Online, 1. Retrieved from https:// dspace.lboro.ac.uk/2134/633

Audretsch, D. B., Kuratko, D. F., \& Link, A. N. (2016). Dynamic entrepreneurship and technology-based innovation. Journal of Evolutionary Economics, 26(3), 603-620. doi: 10.1007/so0191-0160458-4

Beckert, J. (2013). Capitalism as a system of expectations toward a sociological microfoundation of political economy. Politics and Society, 41(3), 323-350. doi: 10.1177/0032329213493750

Benavente, J. (2003). Informe sobre el proceso emprendedor en Chile. Washington, USA: Banco Interamericano de Desarrollo.
Birch, D. L. (1979). The job generation process. Unpublished report prepared by the MIT Program on Neighborhood and Regional Change.

Birch, D. A. (1981). Who creates jobs? The Public Interest, 65, 3-14.

Boltanski, L., \& Chiapello, E. (1999). El nuevo espíritu del capitalismo. Madrid, España: Akal.

Boltanski, L., \& Thèvenot, L. (2006). On justification: The economies of worth. Princeton, USA: Princeton University Press.

Bröckling, U. (2015). El self emprendedor: Sociología de una forma de subjetivación. Santiago, Chile: Ediciones Universidad Alberto Hurtado.

Brown, S. D. (2001). Psychology and the art of living. Theory \& Psychology, 11(2), 171-192. doi: 10.1177/0959354301112002

Casson, M. (1990). Entrepreneurship. international library of critical writings in economics. London, UK: Edward Elgar Publishing Ltd.

Colonomos, A. (2005). The morality of belief in the profits of virtue. International Social Science Journal, 57(185), 457-467. doi: 10.1111/j.1468-2451.2005.00563.x

Consejo Nacional de Innovación para el Desarrollo. (2006). El sistema chileno de innovación: Background report. Recuperado de http:// www.cnid.cl/portfolio-items/el-sistema-chileno-de-innovacionbackground-report

Corporación de Fomento de la Producción. (2012). Generación neta de empleo. Santiago, Chile: CORFO.

Corporación de Fomento de la Producción. (2014a). Emprendimiento en Chile: Hacia un modelo de segmentación. Santiago, Chile: CORFO.

Corporación de Fomento de la Producción. (2014b). Fundamentos administrativos para la operación de incubadoras. Santiago, Chile: CORFO.

Deleuze, G., \& Guattari, F. (1980). Capitalisme et schizophrénie (vol. 2, p. 645). Paris, France.

Duvall, R. D., \& Freeman, J. R. (1981). The state and dependent capitalism. International Studies Quarterly, 25(1), 99-118. doi: $10.2307 / 2600212$

Finnemore, M., \& Sikkink, K. (1998). International norm dynamics and political change. International Organization, 52(4), 887-917. doi: $10.2307 / 2600212$

Fleming, W. J. (1979). The cultural determinants of entrepreneurship and economic development: A case study of Mendoza Province, Argentina, 1861-1914. The Journal of Economic History, 39(1), 211-224. doi: $10.1017 /$ So022050700096406

Fontaine, J. A. (1993). Transición económica y política en Chile: 19701990. Estudios Públicos, 50, 229-279.

Foucault M., (2008). The birth of biopolitics: Lectures at the Collége de France 1978-1979. London, UK: Palgrave Macmillan.

Germani, G. (1972). Mass immigration and modernization in Argentina. In W. Petersen (Ed.), Readings in population (pp. 223-241). New York,USA: Macmillan.

Goodwin, C. (2018). Co-operative action. Boston, USA: Cambridge University Press. 
Harding, D. (2007). Cultural context, sexual behavior, and romantic relationships in disadvantaged neighborhoods. American Sociological Review, 72(3), 341-364. doi: 10.1177/000312240707200302

Harvey, D. (2005). A brief history of neoliberalism. New York, USA: Oxford University Press.

Holstein, James and Gubrium, Jaber. 2013. Práctica Interpretativa y Acción Social. In Norman Denzin and Ivonna Lincoln (eds). Manual de Investigación Cualitativa Vol III (pp. 228-269). Barcelona, Espanha: Gedisa.

Imas, J. M. (2005). Rational darkness: Voicing the unheard in the modern management discourse of Chile. Administrative Theory \& Praxis, 27(1), 111-133. doi: 10.1080/10841806.2005.11029473

Imas, J. M. (2010). Dirty management': The legacy of Chile and Argentina. In A. Guedes, \& A. Faria (Eds.), International Management and International Relations a Critical Perspective from Latin America ( $\mathrm{pp}$. 185-200). London, UK: Routledge.

Imas, J. M., Wilson, N., \& Weston, A. (2012). Barefoot entrepreneurs. Organization, 19(5), 563-585. doi: 10.1177/1350508412459996

Kaulingfreks, R., Lightfoot, G., \& Letiche, H. (2009). The man in the black hat. Culture and Organization, 15(2), 151-165. doi: $10.1080 / 14759550902925328$

Kantis, H. (2004). Nacimiento y desarrollo de empresas dinámicas en América Latina", desarrollo emprendedor: América Latina y la experiencia internacional. Washington, USA: Banco Interamericano de Desarrollo (BID).

Keith, William \& Rehg, William. (2007). Argumentation in Science and Technology Studies. In O. Amsterdamska, E. Hackett, M. Lynch and J. Wajcman (Eds.), The Science Studies Handbook (pp. 211-239). Massachusetts, EUA: MIT Press

Kirzner, I. M. (1973). Competition and entrepreneurship. New York, USA: The University of Chicago Press.

Lamont, M. (1994). Money, morals and manners: The culture of the French and American upper-middle class. Chicago, USA: The University of Chicago Press.

Lamont, M., \& Small, M. (2008). How culture matters: Enriching our understanding of poverty. In D. Harris, \& A. Lin (Eds.), The colors of poverty: Why racial disparities persist (pp. 76 -102). New York, USA: Russell Sage Foundation.

Lazonick, W. (2011). Entrepreneurship and the developmental state. In W. Naudé (Ed.), Entrepreneurship and economic development (pp. 254-270). London, UK: Palgrave Macmillan.

Lipset, S. M. (1967). The first new nation: The United States in historical and comparative perspective. London, UK: Transaction Publishers.

Longueira, P. (2012). Speech inaugurating the 2012 Global Entrepreneurial Week. Retrieved from http://www.youtube.com/ watch?v=byзyoTzguQA

Lundstrom, A., \& Stevenson, L. A. (2005). Entrepreneurship policy: Theory and practice. Boston, USA: Springer.

Mandakovic, V., Cohen, B., \& Amorós, J. E. (2015). Entrepreneurship policy and its impact on the cultural legitimacy for entrepreneurship in a developing country context. In Marta Peris-Ortiz, José M. MerigóLindahl (Eds.), Entrepreneurship, Regional Development and Culture (pp. 109-125). Springer. doi: 10.1007/978-3-319-15111-3_7
Marttila, T. (2018). Neoliberalism, Knowledge-Based Economy and Metaphorization of the Entrepreneur to the Subject of Creativity. In Damien Cahill, Melinda Cooper, Martijn Konings and David Primrose (Eds.) The Sage Handbook of Neoliberalism (Chp. 42). London, UK: Sage

Max-Neef, M., Elizalde, A., \& Hopenhayn, M. (1990). Human scale development: an option for the future. Santiago, RM: Development Alternatives Centre [Centro de Alternativas de Desarrollo] (CEPAUR).

Mazzucato, M. (2011). The entrepreneurial state. Soundings, 49(49), 131-142. doi: $10.3898 / 136266211798411183$

McNay, L. 2009. Self as Enterprise. Dilemmas of Control and Resistance in Foucault's The Birth of Biopolitics. Theory, Culture \& Society 26(6): 55-77. doi: 10.1177/0263276409347697

Ministerio de Hacienda. 2012. Ley de Presupuestos del Sector Público año 2012. Ley 20.557 publicada en el diario oficial del 15 de diciembre de 20111. Andros Impresores: Santiago.

Monitor, G. E. (2018). Global Report 2017/18. London, UK: Global Entrepreneurship Research Association (GERA).

Naudé, W. (2011). Is pro-active government support needed for entrepreneurship in developing countries. In W. Naudé (Ed.), Entrepreneurship and economic development (pp. 233-253). London, UK: Palgrave Macmillan. doi: 10.1057/9780230295

Organisation for Economic Co-operation and Development. (1996). Lifelong learning for all. Paris, France: OECD.

Örge, Ö. (2013). Entrepreneurship policy as discourse: Appropriation of entrepreneurial agency. In F. Welter, R. Blackburn, E. Ljunggren, \& B. W. Amo (Eds.), Entrepreneurial business and society (pp. 37-57). Cheltenham, UK: Edward Elgard.

Perren, L., \& Jennings, P. L. (2005). Government discourses on entrepreneurship: Issues of legitimization, subjugation, and power. Entrepreneurship Theory and Practice, 29(2), 173-184. doi: 10.1111/j.1540-6520.2005.00075.x

Potter, J. (1996). Representing reality: Discourse, rhetoric and social construction. London: UK: Sage.

Potter, J., \& Wetherell, M. (1987). Discourse and social psychology: Beyond attitudes and behaviour. London, UK: Sage.

Prahalad, C. (2006). The fortune at the bottom of the pyramid. Pensylvania, USA: Wharton School Publishing.Schumpeter, J. A. (2014). Capitalism, socialism and democracy (2nd ed.). Floyd, USA: Impact Books. (Publicado originalmente em 1942)

Sengupta, H. (2014). Recasting India: How Entrepreneurship is Revolutionizing the World's Largest Democracy. Nova York, EUA: St. Martin's Press.

Schwellnus, C. (2010). Chile: Boosting productivity growth by strengthening competition, entrepreneurship and innovation [Working Paper $\mathrm{N}^{\circ} 785$ ]. OECD.

Sombart, W. (1913). Die deutsche Volkswirtschaft im neunzehnten Jahrhundert. Berlin, Germany: Georg Bondi.

Swidler, A. (1986). Culture in action: Symbols and strategies. American Sociological Review, 51, 273-286.Taylor, C. (1989). Sources of the self: The making of the modern identity. Cambridge, USA: Harvard University Press. 
Thatcher, M. (1996). Liberty and limited government. Speech presented at Centre for Policy Studies Keith Joseph Memorial Lecture. London, UK. Retrieved from https://www.margaretthatcher.org/ document/108353

Tirado, F., \& Domènech, M. (2009). El problema de la agencia en psicología social: Retos y perspectivas. In J. Loredo, T. Sánchez-Criado, \& D. López (Eds.), ¿Dónde reside la acción? Agencia, constructivismo y psicología (pp. 237-290). Murcia, Spain: UNED.

Weber, M. (1975). La ética protestante y el espíritu del capitalismo. Barcelona, España: Ediciones Península. (Publicado originalmente em 1905)
Weiskopf, R., \& Steyaert, C. (2009). Metamorphoses in entrepreneurship studies: Towards an affirmative politics of entrepreneuring. In D. Hjorth, \& C. Steyaert (Eds.), The politics and aesthetics of entrepreneurship (pp. 183-201). Cheltenham, UK: Edward Elgar.

Young, A. (2004). The minds of marginalized black men: Making sense of mobility, opportunity, and future life chances. Princeton, USA: Princeton University Press.

Zárate, V.V. O. de. (2010). ¡Estamos en guerra, señores!: El régimen militar de Pinochet y el "pueblo", 1973-1980. Historia (Santiago), 43(1), 163 201. doi: $10.4067 /$ So717-71942010000100005

\section{AUTHORS' CONTRIBUTIONS}

The authors declare that they contributed equally in the paper development, conceptualization and theoreticalmethodological construction, theoretical review (literature survey), writing and, final review. The data collection was conducted by first author. 